.

\title{
DAMPAK BELANJA PEMERINTAH TERHADAP KONVERSI HUTAN KE PERTANIAN DI INDONESIA
}

\section{THE EFFECT OF GOVERNMENT SPENDING ON LAND USE CONVERSION FROM FOREST TO AGRICULTURE IN INDONESIA}

\author{
Widyaningsih Ratna Puspitasari \\ Kementerian Lingkungan Hidup dan Kehutanan \\ Gedung Manggala Wanabakti Blok 7 Lantai 14, Jl. Gatot Subroto, Senayan \\ Jakarta Pusat, DKI Jakarta 10270 \\ e-mail :soleosa@gmail.com
}

Naskah diterima: 8 September 2018; revisi terakhir: 31 Oktober 2018; disetujui: 8 November 2018

\begin{abstract}
This study analyzes the impacts of government spending on land use conversion from forest to agriculture based on national budget allocation in Indonesia. As agriculture expansion and the government spending on agriculture increase especially during this more than ten-year period, it is suspected that the conversion of land from forest to agriculture gradually increases. Therefore, the increase of government spending on agriculture may be one of the contributing factors to deforestation. Balanced panel data from 33 provinces in Indonesia that covers a ten-year period between 2006 and 2015 was used to examines the indirect effects of government spending on agriculture, total government spending over GRDP, and public spending on land use conversion. The generalized method of moment estimation (GMM) technique was applied in this research to investigate relationship between government spending and deforestation. The result showed that there is an indirect impact from increasing government spending: there is an increase in the total amount of land use conversion from forest to agriculture in Indonesia. This study depicts that an increase in government spending on agriculture and total government spending over GRDP have a significant positive impact on deforestation. Meanwhile, public spending has no significant effect on deforestation.
\end{abstract}

Keywords: Deforestation, GMM, government spending 


\begin{abstract}
Abstrak
Penelitian ini bertujuan untuk menganalisa dampak belanja pemerintah terhadap deforestasi, berdasarkan anggaran nasional belanja pemerintah di Indonesia. Meningkatnya perluasan lahan pertanian yang diikuti dengan peningkatan belanja pemerintah untuk sektor pertanian dalam kurun waktu lebih dari 10 tahun terakhir ini memungkinkan terjadinya peningkatan konversi lahan. Peningkatan belanja pemerintah yang ditujukan untuk sektor pertanian dapat menjadi salah satu faktor pemicu deforestasi. Menggunakan panel data dari 33 provinsi di Indonesia selama 10 tahun, dari tahun 2006 s.d 2015, penelitian ini mengkaji dampak tidak langsung dari belanja pemerintah di bidang pertanian, total belanja pemerintah per PDRB, dan belanja pemerintah di public sector terhadap deforestasi. Menggunakan system generalized method of moment estimation (GMM), penelitian ini menganalisa hubungan antara belanja pemerntah dan deforestasi. Hasil empirik menunjukkan bahwa terdapat dampak tidak langsung dari peningkatan belanja pemerintah: adanya peningkatan konversi lahan dari hutan untuk pertanian. Penelitian ini juga menunjukkan bahwa peningkatan belanja pemerintah di bidang pertanian dan total belanja pemerintah per PDRB memiliki dampak siknifikan terhadap deforestasi. Sedangkan belanja pemerintah untuk sector public tidakmemilikidampakuntukmeningkatkandeforestasi.
\end{abstract}

Kata kunci : Deforestasi, GMM, belanja pemerintah

\title{
A. INTRODUCTION
}

This study examines whether government spending on agriculture contributes to deforestation - in terms of land use conversion from forest to agriculture - in Indonesia. During 2001 - 2008, to stimulate agriculture production, government of Indonesia had increased the national spending on agriculture from $\mathrm{Rp} 11$ trillion to $\mathrm{Rp} 53$ trillion (Armas et al., 2012). Moreover, one of food security priorities program in National Middle-Term Development Plan (RPJMN) 2010 - 2014 is extending agriculture area up to two million hectare areas (National Development Planning Agency, 2010). Therefore, it is interesting to empirically measure the impact of the government spending, which is aimed to boost agriculture sector, on forest degradation. This study is attempted to address the issue.

The government of Indonesia has considered that agriculture is an important sector for Indonesia's economy. In 2015, it contributed 14.3\% to Gross Domestic Product (GDP) and absorbed approximately $0.20 \%$ or around 35.76 million laborers (BPS, 2015), followed by an increase in government spending on this sector every year. Armas et al. (2012) mentioned that agricultural expenditure of Indonesia doubled from 3\% in 2001 to $6 \%$ in 2008. 


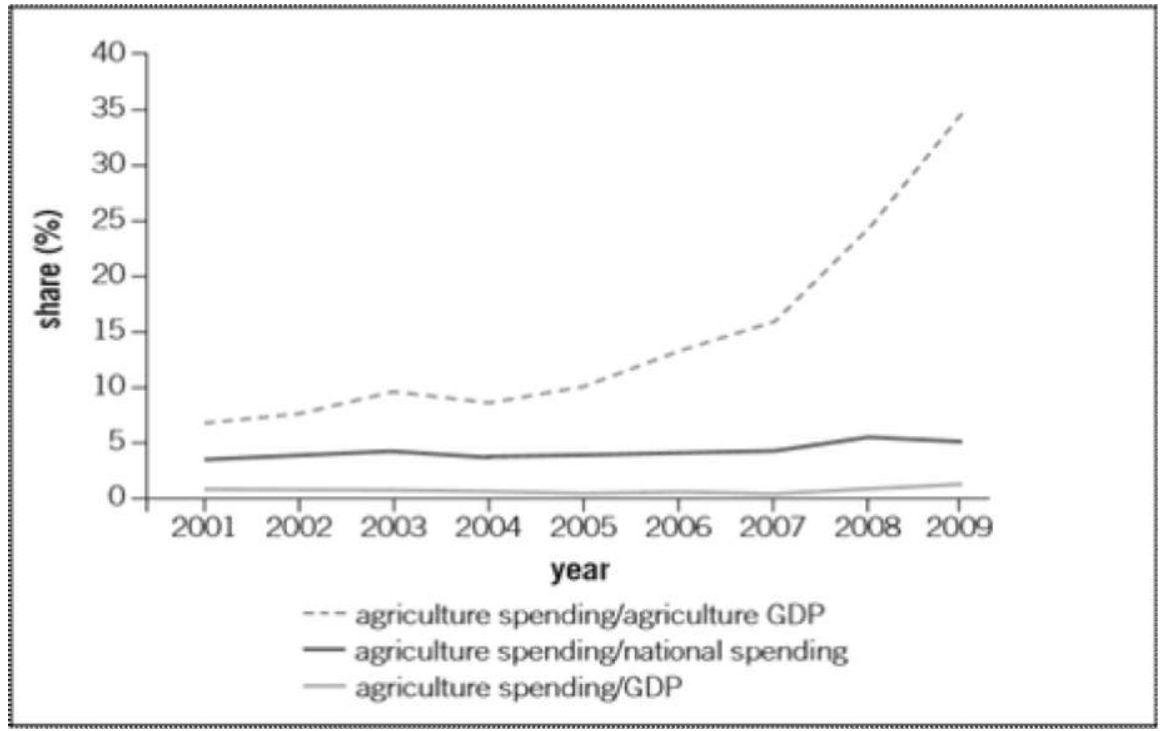

Figure 1.

Agriculture spending in Indonesia, 2001-2008. Reprinted from "Agriculture Public Spending and Growth in Indonesia" (Armas et al, , 2012:10)

In addition, a further study states that government expenditure has an effect on increasing agriculture productivity (Selvaraj, 1993). These studies show that government expenditure on agriculture contributes to promote economic growth in Asia. To achieve this goal, agricultural expansion is one of the Indonesian government priorities (Ministry of Agriculture (MoA), 2013).

In most developing countries, typically, agriculture is a prime mover of the economic growth - the biggest contributing sector to their GDP and employment (Fan and Rao, 2003; Akroyd and Smith, 2007). Therefore, government spending on agriculture sector has an important role to enhance GDP. A study by Fan and Rao (2003) points out that spending on agriculture in Asia during 1980 to 2002 underwent more than double increase, with the average rate of annual growth at 4.4\%. In addition, a further study states that government expenditure has an effect on increasing agriculture productivity (Selvaraj, 1993). These studies show that government expenditure on agriculture contributes to promote economic growth in Asia. To achieve this goal, agricultural expansion is one of the Indonesian government priorities (Ministry of Agriculture (MoA), 2013).

Deforestation due to the land use conversion from forest to agriculture became a serious problem when the government initiated "Mega Rice Project" (MRP) in Indonesia in 1996 (Yulianti and Hayasaka, 2013). The government, concerned to alleviate the food crisis, commenced to convert one million hectares of peatland forests into rice fields. Nevertheless, this project failed and left considerable damage to the environment. Margano, et al. (2014) report that from 2000 to 2012, Indonesia lost more than 6.02 Mha of its primary forest. In addition, in 2012, 0.84 Mha of primary forest of Indonesia was converted. This number outweighed the number of deforestation of Brazil-0.46 Mha. Land use conversion in Indonesia is frequently driven by agriculture expansion such as palm oil plantations (Austin, et al., 2015). Moreover, a finding from Global Forest Watch (GFW) confirms that the trend of deforestation in Indonesia increased $2001-2016$ (Figure 2). ${ }^{1}$ 


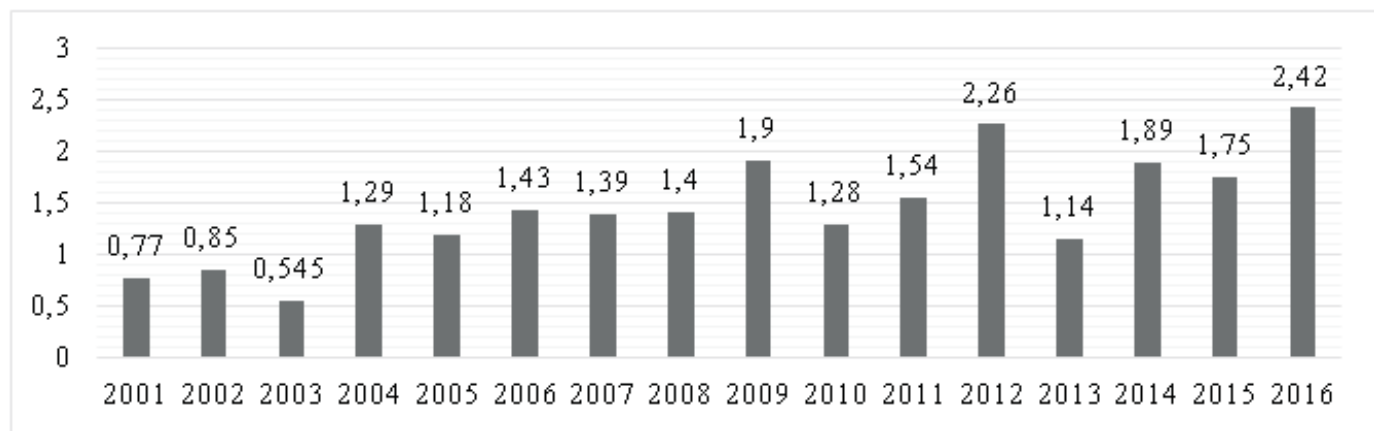

Figure 2.

Deforestation (in Mha) in Indonesia from 2001 to 2016 (GFW, 2018)

Land conversion, especially for palm oil plantations (Weisee, M. \& Peterson.R., 2015; GFW, 2018), becomes a problematic issue between development and environment in Indonesia. Hence, a further study to examine the role of government expenditure on agriculture is important to identify the relation between government spending and deforestation for agriculture purposes in Indonesia.

There have been few studies on the issue of deforestation and government spending. Novra (2007), focusing on a very small region of the country in Sumatra. He examines the effect of government expenditure on deforestation due to agricultural land in a conservation area in Kerinci Seblat National Park (KSNP) in Sumatra, Indonesia. The general objective of the research is to analyze the impact of local government expenditure on the regional deforestation and conservation area degradation. Nevertheless, to capture and assess the deforestation in Indonesia, the area of study need to be improved. Therefore, to differentiate with Novra (2007), this paper would not examine conservation areas only, but will utilize data on government spending and land use conversion in 33 provinces in Indonesia. A research by Galinato \& Galinato (2015) finds the effect of government spending on land use conversion from forest to agriculture in 12 countries for 1986 - 1999 and focusing on the impacts of two government expenditure: total government spending over GDP and government spending on public sector. Meanwhile, this study is expected to provide the relationship between government expenditure on agriculture and forest land clearing for agriculture purposes.

Considering these issue, this study will address the research question: Do government spendings have an indirect impact to increase land use conversion?. This research aims to achieve the following goals: 1) to investigate the indirect relationship between government spending and land use conversion from forest to agriculture in Indonesia, and 2) to analyze factors that influence government spending on land use conversion in Indonesia. In addition, the study employs a panel data estimation model consisting of 33 provinces in Indonesia for the time period $2006-2015$. This research hypothesizes that during a ten-year, as Indonesian agriculture expanded and agriculture spending increased, the conversion of land from forest to agriculture had also been increasing. This study focuses on the indirect impact between government expenditure and deforestation from forest to agriculture. The findings of this study will be useful for local governments that are responsible for allocating budget for agriculture and could support forestry and financial policies recommendations to eliminate deforestation in Indonesia.

'Global Forest Watch (GFW) is an online forest web application to monitor global forests in near real-time. GFW convened by the World Resources Institute (WRI) and partners including Google, USAID, the (UMD), concerned government, NGOs, public, and private organizations (www.wri.org). 


\section{B. RESEARCH METHOD}

Our sample consists of a total of 33 provinces in Indonesia for the period 2006 2015. In this research, the independent variables that we employ to estimate the impact of government spendings on deforestation due to agriculture purposes are land use conversion for agriculture, government expenditures, crop price index, wage in the agriculture sector, investment, infrastructure and population density. The dependent variable is land use conversion.

\section{Data and Specification}

\section{b.1. Dependent Variable}

\section{Land Use Conversion}

We define land use conversion as the total amount of forest land clearing driven by agriculture purposes in each province in Indonesia. The data of the land use conversion is taken from Ministry of Environment and Forestry (MoEF).

\section{b.2. Explanatory Variables}

\section{Government Spending}

To measure government expenditures, three government expenditures are employed: (i) government spending for agriculture, (ii) total government spending, and (iii) government spending on public goods. This study follows Galinato and Galinato (2015) in calculating aggregate spending and public spending. Proxy of aggregate spending is obtained by dividing total government spending by GRDP. Futhermore, we use a category of government spending on public goods conducted by Lopez and Galinato (2007) which consists spending on education, health, social welfare, transportation, community, environmental protection, culture, and public works. A public spending variable is applied by adding those public expenditures and dividing it by total spending. Meanwhile, share of government spending on agriculture is calculated by dividing government spending on agriculture to total expenditure.

\section{Labor Wages}

The wages for labor hired on this study is the wages in the agriculture sector. It is calculated in Indonesian Rupiah ( $\mathrm{Rp}$ ) for working 4-6 hours/day of labor, retrieved from the Central Statistics Agency/Biro Pusat Statistik(BPS).

\section{Crop Price Index}

Data for crop price index used in this study comes from regency-level data on agriculture commodities such as rice, maize, soybeans, cassava, potaoes, peanuts, tapioca, copra, black pepper, white pepper, and rubber. Angelsen and Kaimovitz (2000) mention that higher agricultural prices would result in increased forest clearing. Rudel (1998) argued that price increases in the agriculture sector may lessen deforestation in the long-run. He shows that even though higher agricultural prices lead to deforestation in the short-run, in the long-run prices may provide incentives to conserve the forest, and thus the effect on forest clearing becomes negative. The data set is retrieved from BPS.

\section{Investment}

We use domestic investment as a investment variable in this study. Investment is calculated in billion Rupiah, the data set is retrieved from BPS.

\section{Initial Forest Cover}

The rate of deforestation may be induced by either the vastness or scarcity of forest, 
therefore, it is important to include initial forest cover in given provinces (Shandra, 2007). Due to data limitation of total forest cover area, we use the number of total land area of the provinces for a proxy of the initial forest cover. The data is retrieved from BPS.

\section{Infrastructure}

Angelsen and Kaimovitz (2000) mentions that new road building or improving existing roads have several consequences: it opens up new areas, reduces transport costs, and provides market access. In the other words, roads will make deforesting activities more profitable. Roads are among the most powerful factors contributing to deforestation across the tropics. In this study we collect data on the kilometers of roads per province for infrastructure variable. These data is collected from BPS.

\section{Population Density}

Population pressure is one of the most significant underlying factors of deforestation. It increase the demand of forest products and land uses. The data are collected from BPS.

\section{Empirical Model and Estimation Method}

To obtain the purpose of this study, we follow a panel data estimation method by Galinato $\&$ Galinato (2015), focusing on government spending impact on deforestation due to land use conversion from forest to agriculture by including several explanatory variables.

$$
\begin{gathered}
\operatorname{lnLUC}_{i, t}=\alpha+\beta_{1} \operatorname{lnLUC}_{i, t-n}+\beta_{2} \operatorname{lnAGRI}_{i, t-1}+\beta_{3} \operatorname{lnGSO}_{i, t-1}+\beta_{4} \ln P U B L I C_{i, t-1} \\
+\beta_{5} \ln W A G E_{i, t-1}+\beta_{6} \ln P R I C E_{i, t} \\
+\beta_{7} \operatorname{lnINVEST_{i,t}}+\beta_{8} \operatorname{lnLANDPROV}_{i, t}+\beta_{9} \ln I N F R_{i, t} \\
+\beta_{10} \operatorname{lnPOPDEN}_{i, t}+\mu_{i, t}
\end{gathered}
$$

where subcripts $i$ represent Indonesia's provinces and $t$ represents the time period from 2006 to $2015 . \alpha$ is the constant intercept parameter estimation, $\beta_{1}$ to $\beta_{10}$ represent the slope of parameters estimation, and $\mu_{i, t}$ represents the error term. $L U C_{i, t}$ and $\ln L U C_{i, t-1}$ are the amount of land use conversion for agriculture in province $i$ at year $t$ and $t-1$; $A G R I_{i, t-1}$ is the share of government spending on the agriculture sector in province $i$ at time $t-1 ; G S O_{i, t-1}$ is government expenditure over gross regional domestic product (GRDP) in province $i$ at time $t-1 ; P U B L I C_{i, t-1}$ is share of government expenditure on public goods in province $i$ at time $t-1 ; W A G E_{i, t-1}$ is wages in the agriculture sector in province $i$ and time $t-1 ; P R I C E_{i, t}$ is an index of crop prices in province $i$ and time $t$; $I N V E S T_{i, t}$ is domestic investment in in province $i$ and time $t ; L A N D P R O V_{i, t}$ is land area of the province which is a proxy for the initial forest cover; $I N F R_{i, t}$ is length of roads of the province which is a proxy for infrastructure in province $i$ and time $t$; and POPDEN $i, t$ is population density in province $i$ and time $t$.

Due to several econometric problems that may appear, there are several things that should be noted regarding the estimation model above. To obtain consistent estimates given a fixed sample size, the empirical study by Arellano-Bond (1991) shows that estimation of dynamic panel model requires the use of difference Generalized Method of Moment (GMM). Previous study by Galinato \& Galinato (2015) propose a model by increasing the number of lagged on dependent variable until the lags effect become insignificant. In addition, we assume that crop price index may be the subject of endogeneity problem. It may have reverse causality with land use conversion or it may correlate with the error term. Regard with reverse causality 
problem, this study lagged the government spending and wages variables to reduce the possibility of reverse causality. In addition, Connolly \& Li (2016) argue that there are two problems of OLS estimation. First, the lagged dependent variable is correlated with the country specific effect which leads to the dynamic panel bias. Second, variable in the explanatory variables are endogenous.

\section{CONCEPTUAL FRAMEWORK}

This study focus on the indirect effect of government spending on forest conversion for agriculture purposes. The equation model of government spending and land use conversion developed by Galinato \& Galinato (2015) is employed. Government expenditure, $G$, is divided into government expenditure for private goods $(g)$ and government expenditure for public goods $(x)$. Galinato and Galinato assume that the government's budget constraint holds where $G=g+x$

The initial model is as follows:

$Y_{t}=\mathrm{Y}\left(K_{t}, L_{t}, F_{t}, A_{t}, g, x\right)$

where $Y_{t}$ denotes the agriculture production at time t, $K_{t}$ is capital at time t, $L_{t}$ is labor at time $\mathrm{t}, F_{t}$ is amount of forest cover at time $\mathrm{t}$, and $A_{t}$ is the amount of forest land cleared at time $\mathrm{t}$.

Applying Galinato \& Galinato (2015) and Lopez \& Galinato (2007) the change in forest cover is expressed as:

$F_{t}-F_{t-1}=\alpha F_{t}-\beta A_{t}$

$\alpha$ is forest natural growth rate, $\beta$ is a proportion of forest cover decline for agriculture. Further Galinato and Galinato (2015) assume that farmers optimally select labor and capital to maximise the profit, hence:

$\pi\left(F_{t}, A_{t}, g, x, w, r, p\right) \equiv \max _{K_{t}, L_{t}}\left\{p Y\left(K_{t}, L_{t}, F_{t}, A_{t}, g, x\right)-w L_{t}-r K_{t}\right\}$

where $p$ is price of agricultural production, $w$ is wage rate, $r$ is capital price. Further, they explain that government spending has direct effect to choose capital and labor. First order condition with respect to each variable input shows value marginal product is equal to the input price:

$\frac{d \pi}{d L}=p Y_{L}\left(K_{t}, L_{t}, F_{t}, A_{t}, g, x\right)-\mathrm{w}=0$

$\frac{d \pi}{d K}=p Y_{K}\left(K_{t}, L_{t}, F_{t}, A_{t}, g, x\right)-\mathrm{r}=0$

with the assumption $\frac{\partial K}{\partial A}>0$ and $\frac{\partial L}{\partial A}>0$

Galinato \& Galinato (2015) determine the indirect effect of government spending on land use conversion by maximizing the optimal level of forest clearing for agriculture, it is written :

$\max _{A} \pi\left(\left(F_{t}, A_{t}, g, x, \mathrm{w}, \mathrm{r}, \mathrm{p}\right)-c(g) A_{t}\right.$

where $c(g)$ is the cost of land clearing and is assumed $c_{g}>0$.

First order condition, $V$, shows that:

$\frac{d \pi}{d A}=V \equiv \pi_{A}\left(\left(F_{t}, A_{t}, g, x, \mathrm{w}, \mathrm{r}, \mathrm{p}\right)-c(g)=0\right.$

The value of marginal product of $A_{t}$ is equal to marginal cost of land clearing. The farmers decide to convert forest to agriculture production is depend on (7), hence:

$A_{t}^{*}=H\left(F_{t}, \sum_{j=0}^{t=1} A_{j}, g, x, p, r, w\right)$

Subtitute equation (8) into equation (2) to measure the impact of government spending on public goods on forest clearing:

$F_{t}=\left(\frac{1}{1-\alpha}\right){ }^{\mathrm{t}} F_{0}-\beta \sum_{n=0}^{t=0}\left(\frac{1}{1-\alpha}\right) A_{t-n}=F\left(F_{0}, A_{t}, \ldots, A_{t-n}\right)$ 
where $F_{0}$ is the initial forest stock and $A_{t-n}$ is lagged forest land cleared for gariculture purposes. Employing equation (8) and (9), Galinato and Galinato find:

$A_{t}^{*}=H\left(s, 1-s, \dot{G}, p, r, w, F_{0}, A_{t}, \ldots, A_{t-n}\right)$

Further, the estimation of the relationship between land cleared for agriculture and government spending can be written as follows:

$$
\begin{gathered}
\ln A_{i, t}=\alpha_{1} \ln S_{i, t}+\alpha_{2} \ln \dot{G}_{i, t}+\alpha_{3} \ln p_{i, t}+\alpha_{4} \ln r_{i, t}+\alpha_{5} \ln w_{i, t}+\alpha_{6} \ln F_{0 i} \\
+\sum_{n=1}^{x} \alpha_{6+n} \ln A_{i, t-n}+\varepsilon_{i}+\sigma_{t}+\mu_{i, t}
\end{gathered}
$$

where $i$ and $t$ denote country and time, $\alpha_{j}$ are fixed parameters, $S_{i, t}$ is the share of public good expenditure in country $i$ at time $t$. $\dot{G}_{i, t}$ is government consumption spending over GDP. $F_{0 i}$ is the proxy for initial forest cover that represented by land area of the country. $\varepsilon_{i}$ is a country effect, $\sigma_{t}$ is a time effect, $\mu_{i, t}$ is random disturbance.

Deforestation in Asia has continued to increase rapidly from 2000 to 2010 (Miettinen, Chenghu, \& Liew, 2011), which occurred in the context of major demographic and economic changes. Agricultural expansion has been argued as the most significant direct factor of deforestation (Angelsen \& Kaimovitz, 2000; Selvaraj, 2003). In 2001, the Food and Agriculture Organization (FAO) points out that in developing countries, two-thirds of forest areas were changed by agricultural land expansion, the most significant factor in deforestation (Angelsen \& Kaimovitz, 2000; FAO, 2016). In addition, FAO (2016) reports that there was a forest loss of about six million hectares per year for agriculture land in tropical countries between 2000 and 2010. Other research conducted by Zikri (2009) attempts to develop an economic model for forest clearance in Indonesia by using time series FAO data from 1961 ? 2000. He finds that self-sufficiency in rice production and rice exports are primary goals of the agriculture sector. The pressure on forest lands has been widely recognized to meet the growing needs of the agricultural sector for food self-sufficiency. Deforestation for agriculture purposes, moreover, frequently occurs to achieve food security.

Lopez, Galinato, \& Islam (2011) provide a theoretical basis for determining environmental impact of a change in government spending. They have exposed that reallocation of government spending toward public goods will reduce negative impacts on environmental quality. ${ }^{2}$ In particular, an increase in the share of spending on public goods significantly decreases air pollution. Halkos \& Paizanos (2013) confirm these findings. They examined the impact of government spending on environment using a panel data of 77 countries for the time period 1980 - 2000, indicating that level and composition of fiscal spending significantly affects pollution levels. In addition, they mention that government spending lowers carbon emissions level significantly.

Thorough studies on the impacts of government spending on forest clearing are relatively few in number. Recent research shows that government spending is an important factor to determine environmental quality (Lopez, Galinato, \& Islam, 2011; Halkos \& Paizanoz, 2013). Regarding this phenomena, Angelsen \& Kaimovitz (2000) mention that a major cause of deforestation is forest conversion for agriculture purposes. However, although agriculture is the main direct factor of deforestation, the agriculture sector in Indonesia plays an important role in economic growth (World Bank, 2010). BPS (2015) notices that agriculture contributed $13.45 \%$ to Indonesia's GDP-the third biggest contributor of GDP after manufacturing and service sectors. Agriculture public expenditure, therefore, has increased considerably in recent years.

${ }^{2}$ Public goods have two defining characteristics: (i) Non-excludable-if the goods are available to one person, others cannot be excluded from its advantages. (ii) Non-rival-if the goods are consumed by one person, it does not reduce the amount available to others (Cooper, Hart, \& Baldock, 2009). 
In this regard, there is a lot of literature that, in general, examines fiscal policy and its effect on the environment. Lopez \& Galinato (2007) investigate the relationship between subsidize private and public goods with environment by using a data set from 15 Latin American countries from 1985 - 2001. ${ }^{3}$ Their empirical evidence points out that a higher government spending on private goods makes agriculture dependent on expansion of land area rather than intensification, thus increasing the negative effect of agriculture on forests.

Other research about government spending's impact on deforestation was conducted by Novra (2007). He scrutinizes the effect of government expenditure on deforestation due to agricultural land in a conservation area in Kerinci Seblat National Park (KSNP) in Sumatra, Indonesia. The general objective of the research is to analyze the impact of local government expenditure on the regional deforestation and KSNP degradation. Employing panel data model for three regions, during 1994 to 2003, by using Seemingly Unrelated Regressions (SUR) and Two Stage Least Square (2SLS) estimations, the findings show that an increase in government spending on the agriculture sector tends to increase deforestation in the conservation area. Moreover, he concludes that to achieve regional sustainable development, local government needs to redesign its expenditure by prioritizing human resources development. In addition, Novra (2007) stated that on the revenue side, Gross Regional Domestic Product (GRDP), as an indicator of development, causes greater pressure on land resources including forest areas. Forest management, which is more oriented to increasing GRDP, has a tendency to push the exploitation of resources. This is portrayed by the increased conversion of forest areas into other utilization especially agriculture.

The latest study conducted by Galinato \& Galinato (2015) shows that govenment spending on public goods increases deforestation and carbon emissions. Examining the effect of the fiscal spending on deforestation due to agricultural land expansion in 12 developing countries in Asia (China, Philippines, Thailand, India) and Latin America (Brazil, Argentina, Costa Rica, Ecuador, Mexico, Panama, Nicaragua, Venezuela) using Ordinary Least Square (OLS), Fixed Effect (FE), Random Effect (RE), and Generalized Methods of Moment (GMM) estimations, the results of the study showed that an increase in total government spending significantly increased forest land clearing for agricultural production in the short term. Furthermore, local government may affect the agricultural sector based on their expenditure allocation. The study by Galinato \& Galinato (2015) shows the effect of changes in government expenditure on land use conversion from forest to agriculture. In addition, they also show that an increase in the total government spending results in a significant increase in land clearing for agricultural production. Also, they added that permanent changes in the composition of government expenditure do not have any effect on forest land clearing for agricultural production.

\section{RESULT AND DISCUSSION}

The statistical summary of the variables used in this study is presented in Table 1. The summary explains the correlation between deforestation and its potential determinants.

\footnotetext{
Countries list : Argentina, Brazil, Costa Rica, Ecuador, Guatemala, Honduras, Jamaica, Mexico, Nicaragua, Panama, Paraguay, Peru, Dominican Republic, Uruguay and Venezuela
} 
Table 1.

Summary Statistics of Variables

\begin{tabular}{lcrrrr}
\hline \multicolumn{1}{c}{ Variable } & Obs & Mean & $\begin{array}{l}\text { Standard } \\
\text { deviation }\end{array}$ & Minimum & Maximum \\
\hline $\begin{array}{l}\text { Forest land cleared for } \\
\text { agriculture purposes }\end{array}$ & 295 & $182,545.1$ & $312,821.4$ & 0 & $161,760.3$ \\
\hline $\begin{array}{l}\text { Government spending on } \\
\text { agriculture }\end{array}$ & 295 & 0.0307 & 0.03872 & 0.0033 & 0.3117 \\
\hline $\begin{array}{l}\text { Total government } \\
\text { spending over GRDP }\end{array}$ & 295 & 0.1124 & 0.08773 & 0.0153 & 0.5035 \\
$\begin{array}{l}\text { Government spending on } \\
\text { public sectors }\end{array}$ & 295 & 0.5228 & 0.0938 & 0.1615 & 0.8329 \\
\hline $\begin{array}{l}\text { Wages in agriculture } \\
\text { sector }\end{array}$ & 295 & $39,040.5$ & $15,312.9$ & $13,367.5$ & $105,542.2$ \\
\hline $\begin{array}{l}\text { Agriculture price index } \\
\text { Investment }\end{array}$ & 295 & 98.0235 & 50.4830 & 0 & 161.0800 \\
\hline $\begin{array}{l}\text { Forest land area } \\
\text { Infrastructure (roads) }\end{array}$ & 295 & $54,201.85$ & $62,974.29$ & 664.01 & $319,036.1$ \\
\hline Population Density & 295 & 691.2042 & $2,425.13$ & 2.2881 & $15,327.93$ \\
\hline
\end{tabular}

Applying panel data estimation, this research conducts several tests to gain the most appropriate estimation model among Pooled Least Square, Fixed Effect, and Random Effect estimation (Wooldridge, 2010). However, the presence of lagged dependent variable creates an inconsistency problem in OLS estimation. To address this problem we use System GMM technique. Table 2 presents estimation results of Fixed Effect estimation and System GMM technique.

Table 2.

Regression results for land use conversion for agriculture, 2006 - 2015

\begin{tabular}{l|c|c|c}
\hline \multicolumn{1}{c|}{ Variables } & Fixed Effect & \multicolumn{2}{c}{ System GMM } \\
\hline Lag of land use conversion & & $\begin{array}{c}0.9777^{* * *} \\
(0.0074)\end{array}$ & $\begin{array}{c}0.6010^{* * *} \\
(0.1299)\end{array}$ \\
\hline Second lag of land use & & & $0.3917^{* * *}$ \\
conversion & & & $0.1302)$ \\
\hline Lag of log government & & $0.0923^{* * *}$ & 0.0348 \\
expenditure on agriculture & $(0.0935)$ & $(0.3295)$ & $(0.0365)$ \\
\hline Lag of log government & -2.5087 & $0.1248^{* *}$ & 0.0174 \\
expenditure over GRDP & $(2.2705)$ & $(0.0570)$ & $(0.0655)$ \\
\hline Lag of log government & -0.3798 & 0.1634 & -0.0533 \\
expenditure on public goods & $(0.3308)$ & $(0.1219)$ & $(0.1395)$ \\
\hline Lag of log of wages & -0.2087 & $0.0540^{*}$ & $0.0991^{* *}$ \\
& $(0.2440)$ & $(0.0289)$ & $(0.0388)$ \\
\hline Log of crop price & 0.9236 & 0.2763 & -0.0667 \\
& $(0.8550)$ & $(0.3692)$ & $(0.4287)$ \\
\hline Log of investment & -0.0050 & $-0.0055^{* * *}$ & -0.0023 \\
& $(0.0057)$ & $(0.0014)$ & $(0.0015)$ \\
\hline
\end{tabular}




\begin{tabular}{l|c|c|c}
\hline Log of initial forest cover & $\begin{array}{c}-0.8306 \\
(0.5089)\end{array}$ & $\begin{array}{c}0.1378 \\
(0.1635)\end{array}$ & $\begin{array}{c}0.1121 \\
(0.1745)\end{array}$ \\
\hline Log of infrastructure & $0.3024^{*}$ & -0.1260 & -0.1498 \\
& $(0.1504)$ & $(0.2305)$ & $(0.2342)$ \\
\hline Log of population density & 0.7338 & -0.1404 & -0.0177 \\
& $(0.6520)$ & $(0.0956)$ & $(0.078)$ \\
\hline $\mathrm{R}^{2}$ & 0.2012 & & \\
\hline No. of observations & 295 & 295 & 263 \\
\hline No. of groups & 33 & 33 & 33 \\
\hline No. of instruments & & 32 & 32 \\
\hline Hausman test & $0.000^{* * *}$ & & 0.144 \\
\hline Hansen test & & 0.186 & 0.419 \\
\hline
\end{tabular}

Note : Robust standard error in parantheses. ${ }^{* * *}$ Significance at $1 \%$ level, ${ }^{* *}$ Significance at $5 \%$ level, "Significance at 10\% level. Standard error of fixed effect were obtained using xtreg command. Standard errors from the system generalized method of moments are consistent with panel-specific autocorrelation and heteroskedaticity in two-step estimation. All model employ year dummies.

The estimated coefficient of the lagged logarithm of land use conversion is significant at the $1 \%$ level. It suggests that change in land use conversion has significant effect in the short term. In addition, in the model that includes lagged forest clearing, we find that the effect of two government spending variables are positive and significant in GMM model. In contrast, empirical results in OLS model indicates that government spending over GRDP and government spending on public sector are negative and significant. Moreover, the lagged forest land cleared for agriculture is significant in GMM model and is significant only after second period. Hence, a $1 \%$ increase in land use conversion in the previous period will increase current land clearing by $0.97 \%$. In addition, omitting lagged agricultural land expansion in our model would bias our estimation as presented in fixed effect model.

The most important results on the GMM result are that government spending on agriculture and total government spending over GRDP have a positive and significant effect on forest land clearing. As presented in Table 2, the coefficient of government spending on agriculture is estimated to be positive at the value of 0.09 and highly significant at the $1 \%$ level. In addition, the coefficient of government spending over GRDP is also estimated to be positive and significant at $5 \%$ level with the value of 0.12 only in one lagged land use conversion.

\section{Discussion}

This research investigates the relationship between government spending and deforestation in terms of land use conversion to agriculture purposes. There are three main variables to define these relationship: government spending on agricuture, total government spending over GRDP, and government spending on public sector. The following sections consecutively discuss and analyze these relationships. First, empirical results provide that, ceteris paribus, when government spending on agriculture increases by $10 \%$, forest land clearing rises up to $0.92 \%$. It depicts that allocation of agriculture spending to increase agricultural growth, in fact, has an indirect impact on deforestation. The Indonesian 
government has a concern about the importance of food security. RPJMN in 2010 prioritize agriculture extensification because it is a part of the efforts to enhance agriculture production and to achieve food security (MoA, 2013). Furthermore, Armas et al. (2012) find that agriculture spending allocation for food security and farmer welfare increased, while the allocation to $\mathrm{R} \& \mathrm{D}$ program decreased. They mention that 40 percent of the spending on agriculture has been allocated largely on fertilizer and farmer welfare subsidies since 2009. It means that this budget cannot be used to enhance R\&D program, extension services, or marketing assistance to decrease forest land clearing. Futhermore, Lopez and Galinato (2007) categorize agricultural subsidy as an examples of expenditure on private goods. Large subsidies in private goods, for example seeds, fertilizer, or grants, are proof of increasing deforestation (Fan, Hazel and Thorat., 2000; Lopez and Galinato, 2007).

Second, government spending over GRDP has contributed to an increase in land use conversion. An increase of total government expenditure over GRDP by approximately $10 \%$ may increase land use conversion up to $1.24 \%$, holding other else constant. Galinato and Galinato (2015) find that an increase in total government spending will increase both the government expenditure on public goods and private good. In other words, the bigger the total spending to GRDP, the larger the amount of private spending for subsidize program features. Previous studies point out that government spending on private goods for "social aid" such as subsidies in agriculture sector raise the forest clearing. Therefore, a large share of total spending to private goods spending contributes to deforestation.

Third, in contrast, variable expenditure on public goods has a positive sign but is statistically insignificant to deforestation. One potential explanation is that expenditures on public sector allocation has a role to increases the supply of services that generate important positive externalities, such as environment protection and forest conservation (Lopez and Galinato, 2007). An allocation for restoring forest in Indonesia, such as hydrological restoration by rewetting drained peatland forest restoration, might contribute to reducing forest loss by preventing peatland fires. Therefore, empirical results provide that this budget allocation does not induce land use conversion.

It is also important to note the relationship between wages and land use conversion. The coefficients of wages are estimated to be positive and significant at 5\% and $10 \%$ level, respectively, at all System GMM estimations. This has been observed previously by Angelsen and Kaimovitz (2000), Barbier and Cox (2004) and World Bank (2007). These studies additionally confirm that higher wages can lead to the increasing demand for food. When demand for agriculture production increases, higher wages are associated with higher clearance of forest. Therefore, an increase in wages in agriculture sector has positive impacts on expanding forest clearing.

In term of investment, the coefficient of investment is estimated to be negative and statistically significant at $1 \%$ at one year lagged of dependent variable model. However, insignificant at the second lagged model. Thus, the results imply that an increase in investment may decrease deforestation rate for agriculture. It can be assumed that more invested money could lead to greater conservation outcomes. Shandra (2007) argues that domestic investors have experienced greater pressure from non-governmental organizations to invest in environment. 


\section{E.CONCLUSIONS}

\section{Conclusions}

This paper observes the impact of government spending on deforestation in terms of land use conversion from forest to agriculture purposes. Previous research regarding government spending on deforestation provides an important starting point for understanding this issue. First, the results imply two phenomena: government spending on agriculture and government share of total spending per GRDP lead to increases in forest land cleared. Furthermore, in this study, spending on public sector has an insignificant effect on forest land cleared. Second, this research identifies that wages in the agriculture sector also induce deforestation. An increase in wages may affect forest land clearing through a channel as aforementioned on discussion section. Third, domestic investment, in this research, seems to reduce deforestation.

\section{Policy Implications}

Regarding the main results, some important policy implications might flow from this study. The results imply that allocation of government spending, especially on agriculture and share of aggregate spending, will ultimately increase the pressure on resources and lead to deforestation. Reforestation and regeneration rate is low compared to the rate of forest clearance. It might therefore be more effective to focus on controlling forest clearing by improving environmental policy and institutions. In order to reduce forest degradation it is important for governments to allocate national budget spending on agriculture in the best possible way.

The environmental policy, therefore, is to strengthen environmental management in local government level, particularly in the provinces that have a huge amount of forests. Considering the degradation impact on environment caused by agriculture expansion, it is important to identify the effectiveness of extensification program. Regional plans control for land use conversion has to be solidly executed so that the spatial plan is well implemented and can curb the deforestation. In addition, the key challenge of environmental policy is to ensure that government spendings achieve the environmental objectives. First, World Bank (2010) similarly suggests the Government of Indonesia reallocate agricultural spending. Large subsidizes in private goods, for example seeds, fertilizer, or grants, are proof of increasing deforestation (Fan, Hazel and Thorat, 2000; Lopez and Galinato, 2007). Therefore, maximizing allocation of agricultural spending in public goods, for example irrigation and $R \& D$, are more effective and have positive impacts on the environment. Second, carefully targetfully subsidy programs are important to support poor farmers. To maximize the effectiveness of this program, central government and regional government have to commit with a strong monitoring and evaluation system.

\section{REFERENCES}

Akroyd, S. and Smith, L. (2007). Review of Public Spending to Agriculture. Final Draft. Retrieved from World Bank website: http://www1.worldbank.org/publicsector/pe/pfma07/OPMReview.pdf

Angelsen, A., \& Kaimowitz, D. (2000). Agricultural Technologies and Tropical Deforestation. (A. Angelsen \& D. Kaimovitz, Eds.). Wallingford: CABI Publishing

Arellano, M. \& Bond, S. (1991) Some Test of Specification for Panel Data: Monte Carlo Evidence and An Application to Employment Equation. Review of Economic Studies, 58, 
277-297. http://www.jstor.org/stable/2297968?origin=JSTOR-pdf accessed on June 5th, 2018.

Armas, E. B., Osorio, C. G., Moreno-Dodson, B., \& Abriningrum, D. E. (2012). Agriculture Public Spending and Growth in Indonesia (WPS5977 No. 5977). Retrieved from World Bank website :

http://documents.worldbank.org/curated/en/514581468260113996/pdf/WPS5977.pdf accessed on May 2nd, 2018.

Austin, K.G., et al. (2015). Shifting Patterns of Oil Palm Driven Deforestation in Indonesia and Implications for Zero-Deforestation Commitments. Land Use Policy, 69, 41-48. https://doi.org/10.1016/j.landusepol.2017.08.036

Barbier and Cox (2004). An Economic Analysis of Shrimp Farm Expansion and Mangrove Conversion in Thailand. Land Economics, 80(3), 389-407. https://doi: 10.2307/3654728

Biro Pusat Statistik.(2015). Laju Pertumbuhan Produk Domestik Bruto Atas Dasar Harga Konstan 2000 Menurut Lapangan Usaha (persen), 2000-2014. Retrieved from https://www.bps.go.id/statictable/2009/07/02\%2000:00:00/1202/-seri-2000-lajupertumbuhan-pdb-atas-dasar-harga-konstan-2000-menurut-lapangan-usaha-persen2000-2014.html accessed on February 3rd, 2018.

Copper, T., Hart, K., and Baldock, D. (2009). Provision of Public Goods Through Agriculture in The European Union, Report Prepared for DG Agriculture and Rural Development, Contract No 30-CE-0233091/00-28, Institute for European Environmental Policy : London. Retrieved from https://ieep.eu/archive_uploads/457/final_pg_report.pdf accessed on June 3rd, 2018

Fan, S. and Rao, N. (2003). Public Spending in Developing Countries: Trends, Determination, and Impact. (EPTD Discussion Paper No. 99). Retrieved from International Food Policy Research Institute (IFRI) website:

https://ageconsearch.umn.edu/bitstream/16080/1/ep030099.pdf accessed on June 12, 2018.

Fan, S., Hazell, P., \& Thorat, S. (2000). Government Spending, Growth and Poverty in Rural India. Agricultural and Applied Economics Association. 82(4), 1038-1051. http://www.jstor.org/stable/1244540

Food and Agricultural Organization (FAO), Forest Resources Assessment 2000. (2001). Report of FAO Forest Resources Assessment 2000. Retrieved from http://www.fao.org/forestry/fra/86624/en/ accessed on June 14th, 2018.

Food and Agricultural Organization (FAO), State of The World's Forest. (2016) Report of FAO State of The World's Forest. Retrieved from http://www.fao.org/3/a-i5588e.pdf accessed on June 14th, 2018.

Galinato, G. I., \& Galinato, S. P. (2015). The Effects of Government Spending on Deforestation due to Agricultural Land Expansion and CO2 Related Emissions. Ecological Economics. 122, 43-53. https://doi.org/10.1016/j.ecolecon.2015.10.025

Global Forest Watch. (2018). Tree Loss Cover in Indonesia. Retrieved from http://www.globalforestwatch.org/country/IDN accessed on September 4th, 2017.

Government of Indonesia, Ministry of Agriculture. (2013). Cetak Sawah Indonesia. Retrieved from

http://psp.pertanian.go.id/assets/file/2014/Buku\%20Cetak\%20Sawah\%20Indonesia\%2 0-\%202013.pdf accessed on October 7th, 2017. 
Government of Indonesia, National Development Planning Agency/Ministry of National Development Planning. (2010). Rencana Kebijakan Strategis Perluasan Areal Pertanian Baru Dalam Rangka Mendukung Prioritas Nasional Ketahanan Pangan. Retrieved from: http://hub.satudata.bappenas.go.id/dataset/7052d699-617c-48c5-b02bca909e6cc71e/resource/95ce8c70-660c-4ced-ab38-348f32c577ee/download/rencanakebijakan-strategis-perluasan-areal-pertanian-baru-dalam-rangka-mendukungprioritas-nasi.pdf accessed on May 10,2018.

Halkos, G. E. and Paizanos, E. A. (2013). The Effects of Government Expenditure on Enviroment: An Empirical Investigation. Ecological Economics. 91, 48-56. https://doi.org/10.1016/j.ecolecon.2013.04.002

Jogerson, A.K. (2009). Unequal exchange and environmental degradation : A Theoretical Proposition and Cross National Study of Deforestation. Rural Sociology. 71(4), 685-712. https://doi.org/10.1526/003601106781262016

López, R., \& Galinato, G. I. (2007). Should Governments Stop Subsidies to Private Goods? Evidence from Rural Latin America. Public Economics, 91, 1071-1094. https://doi.org/10.1016/j.jpubeco.2006.10.004

López, R. , Galinato, G.I., Islam A. (2011). Fiscal Spending and The Environment : Theory and Empirics. Journal Environmental Economics and Management. 62(2), 180-198. https://doi.org/10.1016/j.jeem.2011.03.001

Margono, B. A., et al. (2014). Primary Forest Cover Loss in Indonesia over 2000-2012. Natural Climate Change Article, 4, 730-735.

doi: 10.1038/NCLIMATE2277

Miettinen, J., Shi, C., and Liew, S. C. (2011). Deforestation Rates in Insular Southeast Asia Between 2000 and 2010. Global Change Biology, 17(7). doi: 10.1111/j.13652486.2011.02398.x (Global Change biology)

Novra, A. (2007). The Impact of the Local Government Expenditure Allocation on the Regional Deforestation and Kerinci Seblat National Park Degradation (Doctoral dissertation). Retrieved from

http://repository.ipb.ac.id/jspui/bitstream/123456789/40574/1/Cover_2007a no.pdf accessed on February 20, 2017.

Roodman, D.(2006). How to Do xtabond2: An introduction to "Difference" and "System" GMM in Stata (Working Paper No. 103). Retrieved from

http://citeseerx.ist.psu.edu/viewdoc/download?doi=10.1.1.561.6372\&rep=rep1\&type= pdf accessed on March 8th, 2018.

Rudel, T.(1998). Is There a Forest Transition? Deforestation, Reforestation and Development. Rural Sociology. 63, 533-552. https://doi.org/10.1111/j.1549-0831.1998.tb00691.x

Selvaraj, K. N. (1993). Impact of Government Expenditure on Agriculture and Peformance of Agriculture Sector in India. Agriculture Economics, 2(December), 37-49. Retrieved from http://purl.umn.edu/202859 accessed on January 9th, 2018.

Shandra, J.,M. (2007). Economic Dependency, Repression and Reforestation : A Quantitative, Cross National Analysis. Sociology Inquiry, 77(4), 543-571. https://doi.org/10.1111/j.1475-682X.2007.00209.x

World Bank (2007). Spending for Development : Making The Most Of Indonesia's New Opportunities. Indonesia Agriculture Public Expenditure Review 2007. Retrieved from https://openknowledge.worldbank.org/handle/10986/6347 accessed on April 3rd, 2018. 
World Bank (2010). Indonesia Agriculture Public Expenditure Review 2010. No.69346. Retrieved from http://documents.worldbank.org/curated/en/297881468038713079/IndonesiaAgriculture-public-expenditure-review-2010 accessed on June 16th, 2017.

Weisee, M. \& Peterson.R. (2015). Brazil and Indonesia Struggling to Reduce Deforestation. Retrieved from World Resource Institute (WRI) website: www.wri.org accessed on July 1 st, 2017.

Wooldridge, J., M. (2010). Econometric Analysisis of Cross Section and Panel Data, (2 ${ }^{\text {nd }}$ ed.). The MIT Press: Cambridge, Massachusetts.

Yulianti, N. \& Hayasaka, H. (2013). Recent Active Fires under El Niño Conditions in Kalimantan, Indonesia. American Journal of Plant Sciences, 4, 685-696. http://dx.doi.org/10.4236/ajps.2013.43A087

Zikri, M. (2009). An Econometric Model for Deforestation in Indonesia (Working Paper No. 200903). Retrieved from http://ceds.feb.unpad.ac.id/wopeds/200903.pdf accessed on April 11, 2017. 